\title{
Hydrology, light and the use of organic and inorganic materials as structuring factors of biological communities in Mediterranean streams
}

\author{
Sergi Sabater ${ }^{1}$, Helena Guasch ${ }^{1}$, Isabel Muñoz ${ }^{2}$ and Anna Romaní ${ }^{1}$ \\ ${ }^{1}$ Institute of Aquatic Ecology and Dept. Environmental Sciences, Fac. Sciences, Univ. Girona, Campus \\ Montilivi, 17071 Girona, Spain. \\ ${ }^{2}$ Department of Ecology, Fac. Biology, Univ. Barcelona, Av. Diagonal 645, 08028 Barcelona, Spain. \\ Corresponding autor: sergi.sabater@udg.es
}

\begin{abstract}
Hydrological disturbances, light availability and nutrients are the most relevant factors determining the structure of the biological communities in Mediterranean rivers. While some hydrological disturbances are able to induce catastrophic effects, which may cause a complete reset in physical and biological conditions, continued enrichment or changes in light availability are factors leading to the progressive shift in the communities of autotrophs and heterotrophs in the systems. Primary production in Mediterranean streams shows relevant seasonal changes which mainly follows the variations in light availability. In most forested streams, the algal community is shade-adapted. Nutrient enrichment (especially phosphorus) leads to marked increases in primary production, but this increase is not lineal and there is a saturation of algal biomass even in the most enriched systems. The heterotrophs (bacteria, fungi) are related to the pattern of DOC availability (which most depends on the seasonal discharge and leaf fall dynamics) and to the available substrata in the stream. It has been repeatedly observed that shorttime increases of extracellular enzyme activities are related to the accumulation of autochthonous (algal) and/or allochthonous (leaves) organic matter on the streambed during spring and summer, this being more remarkable in dry than in wetter years. Flow reduction favours detritus concentration in pools, and the subsequent increase in the density and biomass of the macroinvertebrate community. In Mediterranean streams collectors are accounting for the highest density and biomass, this being more remarkable in the least permanent systems, in accordance with the effect of floods on the organic matter availability. Nutrients, through the effect on the primary producers, also affect the trophic food web in the streams by favouring the predominance of grazers.
\end{abstract}

Key words: Mediterranean streams, nutrients, metabolism, heterotrophs, chlorophyll, autotrophy, macroinvertebrate community.

\section{RESUMEN}

Los cambios hidrológicos, la disponibilidad de la luz y los nutrientes son los factores más importantes que determinan la estructura y función de la comunidad en los ríos Mediterráneos. Mientras los cambios hidrológicos pueden causar un total reestablecimiento en las condiciones fisicas y biológicas, un aumento continuo de la concentración de nutrientes o cambios en la disponibilidad de la luz, son factores que favorecen un cambio progresivo de las comunidades de autótrofos y heterótrofos. La producción primaria en los ríos Mediterráneos presenta cambios estacionales en función de la luz. En los ríos forestados, las algas están adaptadas a la baja intensidad de la luz. El aumento de la concentración de nutrientes, especialmente el fósforo, favorece la producción primaria pero no de forma lineal, ya que aparece una saturación de la biomasa algal en los sistemas más eutróficos. Los heterótrofos (bacterias y hongos) están más relacionados con la disponibilidad de DOC (que a su vez depende de las variaciones estacionales del caudal y de la dinámica de la caída de las hojas) y de sustrato. Se ha observado, repetidamente, una relación entre el aumento a corto plazo de la actividad exoenzimática y la acumulación de biomasa autóctona algal y/o alóctona (hojas) en el lecho del río, durante la primavera y el verano. Esta relación es más evidente en los años más secos. La reducción del caudal favorece la concentración del detritus en las áreas de menor velocidad de corriente ("pools") y se observa un aumento en la densidad y biomasa de los macroinvertebrados. En los ríos Mediterráneos los recolectores alcanzan las mayores densidades y biomasas, especialmente en los sistemas menos permanentes, en relación con el efecto de las variaciones de caudal sobre la disponibilidad de materia orgánica. Los nutrientes, a través de la producción primaria, tienen un efecto también sobre la estructura de la red trófica, favoreciendo a los ramoneadores.

Palabras clave: Ríos Mediterráneos, nutrientes, metabolismo, heterótrofos, clorofila, autotrofia, macroinvertebrados. 


\section{INTRODUCTION}

Climate, together with the geological setting and river dimensions, is the major factor accounting for differences in streams and rivers worldwide. Biogeochemical characteristics (e.g. Meybeck and Helmer, 1989), hydrological conditions (e.g. Gasith and Resh, 1999) and biological structure and functioning (Margalef, 1983) show consistent differences between rivers from different biomes and ecorregions. In particular, Mediterranean streams host a well-adapted biota (Gasith and Resh, 1999) to the periodic floods and the lasting summer drought that characterize these systems (Lake, 2003; Sabater et al., 1995). Metabolism is the direct response to dynamics of accumulation of organic matter and primary production, modulated by hydrological variations and light availability (Acuña et al., 2004).

Hydrological disturbances are a substantial characteristic of Mediterranean rivers, since extreme episodes (e.g. drought, floods) are integrated in the cyclic temporal pattern in these systems (Armengol et al., 1991). Some of these hydrological disturbances are events which are particularly intense but of low frequency, and are able to induce catastrophic effects, which may cause a complete reset in physical and biological conditions (e.g. Thorndycraft et al., 2005). However, Mediterranean river systems are well adapted to recover after these disturbances, both in terms of its biological structure and functioning (e.g. Sabater et al., 1995), because of their dynamic nature (Margalef, 1983).

Natural-occurring disturbances, particularly related to the hydrology of the systems, cooccur with others linked with human activities (Resh et al., 1988). Anthropogenic disturbances may have different origins and modes of action (e.g. nutrient enrichment, toxicant occurrence, acidification, habitat alteration, network simplification). For instance, toxicants may produce effects not only relevant at different levels of the trophic web (Real et al., 2003), but also may enhance the effects produced by other stressors (Breitburg et al., 1998). Particularly important are the disturbances that lead to nutrient enrichment, since nutrients are able to affect not only the primary producers, but the whole river functioning when they are applied in a continued way (Slavik et al., 2004).

Many factors could be considered in the analysis of the ecological functioning in Mediterranean systems. The present paper summarizes the research being developed in small and medium-sized streams and rivers in NE Spain. These studies have been focused on the structural and functional descriptors that characterize Mediterranean streams under a variety of situations. Both the structure and function in these systems is organised around the type and quality of the inorganic and organic matter available to organisms, modulated by the particular hydrological and climatic conditions. Therefore, an overview is provided on the response of the primary producers, the use of the dissolved organic matter by the heterotrophs, and the role of macroinvertebrate communities in these systems. These descriptors may be considered as the key biological elements in river systems, and adequate representatives of the particular functioning in Mediterranean rivers.

\section{FACTORS INFLUENCING THE ROLE OF THE PRIMARY PRODUCERS IN MEDITERRANEAN STREAMS}

The importance of primary producers is generally expected to increase with increasing aridity (Gasith and Resh, 1999) and mean temperature (Lamberti and Steinman, 1997, Mulholland et al., 2001). The relevance of these two factors in Mediterranean streams justifies the a priori significance that the primary producers might have in these systems (Velasco et al., 2003). Primary production in Mediterranean rivers is highly related to the seasonal variations in river discharge, light and temperature, and nutrients (Armengol et al., 1991, Sabater et al., 1995). Seasonal variations of light and temperature are related to the changes in the canopy cover in the riparian forest. This relationship causes the succession of different algal communities with respect to the governing light regime and the promotion of remar- 
kable differences in their respective photosynthetic efficiencies (Roberts et al., 2004).

In open streams and rivers (River Ter, La Solana), light can easily reach the stream bottom, favouring primary production and enhancing the use of autochthonous organic matter by the consumers. In these Mediterranean systems, primary production is higher when water temperature and light are higher and discharge lower (from late spring until autumn). On the other hand, minimum production occurs in winter, coinciding with low light and temperature (Guasch, 1995). Effects of the primary producers in the river functioning affects even the water chemistry. Dissolved oxygen and carbon dioxide show a clear and opposite pattern of diurnal variation during the period of higher primary production (Guasch et al., 1998). Also the nutrient dynamics is related with primary production. The uptake of phosphate (shorter or longer uptake lengths) varies accordingly to their primary production (Martí and Sabater, 1996). Significant correlation occurs between the phosphate uptake length and the net community primary production $(\mathrm{r}=-0,76, \mathrm{n}=11, \mathrm{p}<0,01)$ (Fig. 1). In situ fertilization experiments confirmed this hypothesis (Guasch et al., 1995). Analogous experiments carried in the two

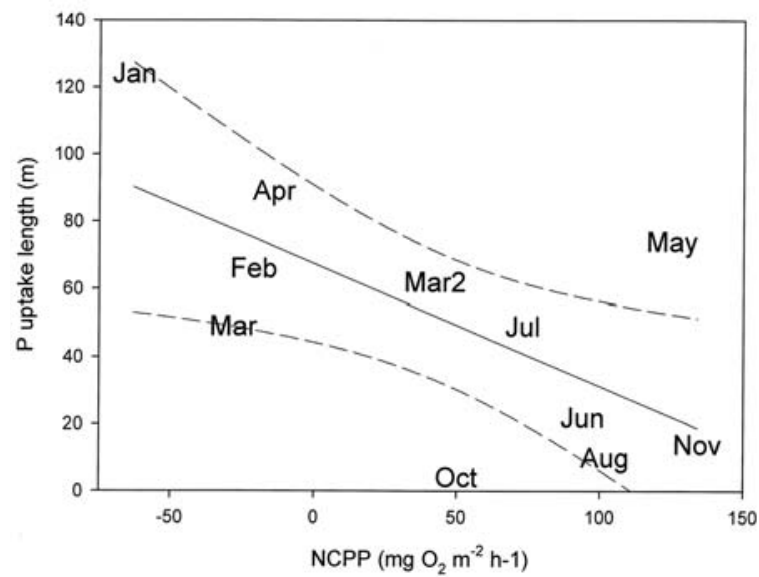

Figure 1. Plot of monthly mean values of Net Community primary Production (NCPP) versus phosphate uptake length (in meters) in La Solana stream during 1992-1993. Plot entre la producción neta de la comunidad y la distancia (en metros) de asimilación del P en La Solana durante el período 1992-93.
Mediterranean climatic extremes (winter and summer) showed that nutrients were a key-controlling factor of primary production, irrelevantly of the temperature.

Seasonal changes in primary production follow the variations in light availability in lightlimited systems (Riera Major, Fuirosos). The primary production is usually higher in winter and spring and lower in summer and early autumn, when the canopy cover is at its maximum (Guasch and Sabater, 1994). The analysis of the photosynthesis-irradiance (P-I) relationships (Guasch and Sabater, 1995) showed that algal community was not light-saturated, and the communities were shade-adapted (high initial response and low saturation irradiance).

Metabolism studies carried in different Mediterranean streams reveal that nutrient concentration, light availability and water flow variability are probably the most important factors in determining annual values of primary production. Reported primary production values (in terms of Gross Community Primary Production) range between $0,05-1,9 \mathrm{gO}_{2} \mathrm{~m}^{2} \mathrm{~d}^{-1}$ in oligotrophic Mediterranean streams (Acuña et al., 2004; Guasch and Sabater, 1994, 1995). However, nutrient enrichment leads to marked increases in primary production. Both in artificially enriched and in naturally enriched systems (e.g. agricultural streams) these values may reach up to 2.4- $2.7 \mathrm{~g} \mathrm{O}_{2} \mathrm{~m}^{2} \mathrm{~d}^{-1}$ (Guasch et al., 1995). An excessive level of nutrients causes nuisance growths of algae and/or cyanobacteria and aquatic plants, with consequences for the water quality and the ecosystem functioning (e.g. Sabater et al., 2003). Figure 2 shows the average algal biomass of different low order streams in a variety of situations. In general, chlorophyll concentration increases with background phosphate concentration (up to $5 \mu \mathrm{M}$ ), but the increase is not lineal. Experimental analyses confirm this asymptotic pattern (Guasch et al., 1995). The photosynthetic efficiency of the community (photosynthesis per unit chlorophyll) is not always enhanced after nutrient addition, indicating that biomass accumulation could depress the photosynthetic capacity of fluvial biofilms. 


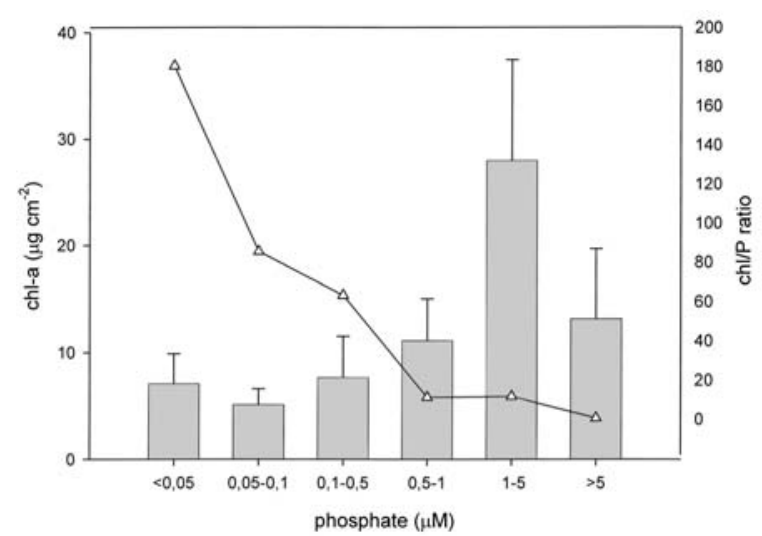

Figure 2. Average and standard error of algal biomass (as chlorophyll concentration) of selected fluvial biofilms growing in low order streams $(n=25)$ differing in the light regime and in the phosphorus status. The streams are arranged according to their respective phosphorus (bars). The corresponding average value of the ratio between chlorophyll and phosphate concentration is also indicated (curve). Valores medios y desviación estándar de la biomasa algal (como concentración de clorofila) de biofilms fluviales en ríos de orden bajo $(n=25)$. Los rios se ordenan en función de su concentración de $P$ (barras). El valor medio de la relación entre clorofila y concentración de P se indica en la curva.

It might be therefore predicted that in streams with similar hydrological features, a reduction in the relationship between chlorophyll content in the biofilm and water phosphate concentration (the Chl/P quotient) is expected as phosphate concentration increases (Fig. 2). High ratios would correspond to undisturbed streams, decreasing exponentially as phosphate concentration increases giving to a linear log$\log$ relation (Fig. 3). The predictable effect of nutrient loading on algal growth in fluvial systems is complicated by the influences of shading (Sabater et al., 2005), stream flow (Stevenson, 1997) or grazing (Biggs, 2000) on algal growth and biomass accrual. The high variability within streams with similar phosphate concentration illustrates this point and the difficulty in separating causes and effects of nutrient status in field studies (Figs. 2 and 3).

Under nutrient-limiting conditions, algal biomass is expected to increase with phosphate availability. It might be assumed that the control of phosphate concentration by algae is possible when the ratio between the active surface in the stream (accounting for the biofilms covering the streambed) and the water is high enough. The highest values of this ratio correspond to open, phosphate-limited streams (Fig. $3)$. The figure 3 also illustrates cases with a chl/P quotient below the confidence interval, indicating that algal biomass is no longer controlling phosphate concentration (RM). These correspond to sites where light is the main limiting factor of primary production. Open streams (B in Fig. 3) with relatively low P concentrations but high chlorophyll show a good control of phosphate by algae and have high chl/P ratio (Serra and Guasch, unpublished data). Phosphorus-rich, open agricultural streams (G) have chl/P higher than expected. In this case, phosphate is not the only factor limiting the algal growth but instead the high availability of both light and nutrients allow high

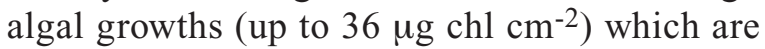
less efficient than thinner biofilms in nutrient removal, but still capable to uptake part of the available phosphate (indicating a remarkable self-purification capacity). The right extreme of figures 2 and 3 illustrate situations ( $\mathrm{Rd}$ and T2) with extremely high phosphate concentration $(>5 \mu \mathrm{M})$, result of the waste water treatment plants discharge in the stream. In these cases, algal biomass is on average lower than in sites receiving lower phosphate concentrations (1-5 $\mu \mathrm{M}$ phosphate). The inhibition of algal growth due to toxicity and/or competition with bacteria capable of using the available organic compounds, may explain this pattern. The complex chemical composition of pollution complicates the establishment of causal relationships between water chemistry and biological responses requiring a simplified experimental approach.

Overall, the response to phosphate and light is complex, and streams may be clustered around five different situations concerning algal growth: nutrient limitation (LS), nutrient and light limitation (RM), light limitation (T1), no limitation ( $\mathrm{G}$ and $\mathrm{F}$ ) and inhibition ( $\mathrm{Rd}$ and $\mathrm{T} 2$ ). It might be hypothesized that the efficiency of these fluvial biofilms on nutrient removal will exponentially decrease following this gradient. 


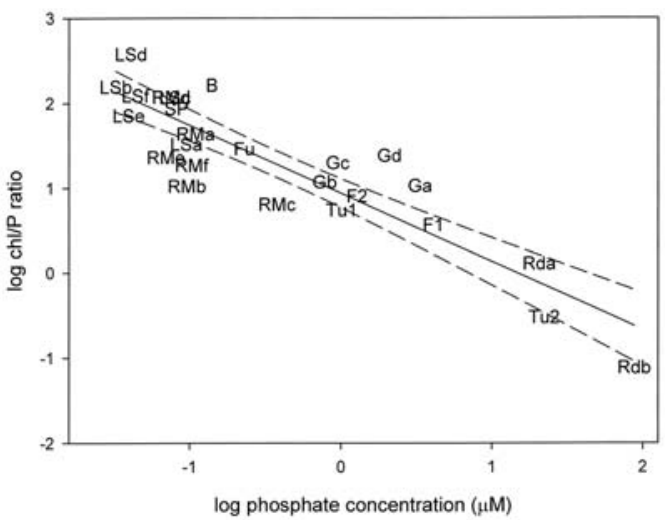

Figure 3. Log-log plot of phosphate concentration versus the chlorophyll/phosphate ratio for the different Mediterranean streams shown in figure 2. LS (La Solana), RM (Riera Major), $\mathrm{B}$ (Bianya), Fu (Fuirosos), G (Gaià), F1 and F2 (Fluvià), T1 and T2 (Turonell, in sites upstream and downstream the inflow of a WWTP effluent) and Riudaura (Rd). For each sampling site, different letters $(\mathrm{a}, \mathrm{b}, \mathrm{c})$ correspond to different sampling periods. Log-log plot de la concentración de fosfato y la relación clorofila/fosfato para diferentes ríos Mediterráneos representados en la figura 2. LS (La Solana), RM (Riera Major), B (Bianya), Fu (Fuirosos), G (Gaià), F1 and F2 (Fluvià), T1 and T2 (Turonell, estaciones aguas arriba y aguas abajo de los aportes de una planta de tratamiento de aguas residuales) y Riudaura $(R d)$. En cada estación de muestreo, las diferentes letras $(a, b, c)$ corresponden a diferentes periodos de muestreo.

\section{USING DISSOLVED AND PARTICULATE ORGANIC MATTER IN MEDITERRANEAN RIVERS}

The moderate size of Mediterranean rivers, and the shallowness of their waters, emphasizes the role of the benthic community as the most important site for the mass transfer of dissolved and particulate organic matter in the whole river ecosystem. This particularity contrasts with other river systems elsewhere, where the planktonic fraction is by far the one having the largest ecological role.

In most cases, rock, cobbles, sand, leaves and wood coexist in a stream reach, and all of these substrata host biological communities with differing structural characteristics. The temporal and spatial heterogeneity of substrata or habitats (alternating pools and riffles) that characterizes Mediterranean river systems, together with the effect of drastic seasonal differences, are the two major driving forces determining the structural-functional characteristics of the benthic biofilm and its role on the carbon cycling in Mediterranean rivers. The extensive studies performed in several Mediterranean river catchments (Riera Major, River Ter, La Solana, Fuirosos) illustrate the effect of these "driving forces" to the patterns of transformation and use of autochthonous and allochthonous organic matter by the carbon consumers.

Allochthonous organic matter is the major energetic basis of food webs in streams with a well-developed riparian forest (Fisher and Likens, 1973; Cummins et al., 1989). Both the abundance and structure of benthic invertebrate communities can be controlled by changes in organic matter resources (e.g., Egglishaw 1964; Cummins et al., 1973; Drake 1984). Temporal variation in food availability in headwater stream reaches is mainly due to the seasonality of litter inputs from the riparian forest, which is also related to the hydrologic regime (e.g. Meyer 1991; Acuña et al., 2004). The dynamics of the benthic organic matter (BOM) in Fuirosos has been observed to change between different hydrologic years. Periods of frequent floods transported BOM downstream and reduced its overall retention in the basin. On the contrary, periods without floods allowed large litterfall accumulations (Acuña et al., 2004).

\section{Heterotrophs using dissolved organic carbon}

The dynamics of the dissolved organic matter in Mediterranean rivers is strongly related to discharge fluctuations. The quantity and quality of dissolved organic carbon (DOC) transported by a river system is the combined result of flushing of the watershed, production of leaves and branches by the riparian vegetation, and in-stream primary production (Sachse et al., 2005). In Mediterranean intermittent streams, the summer drought period causes the temporal mismatch in hydrological connectivity between the surface water and the hyporheic and groundwater. Hydric stress affects the riparian vegetation and can be responsible for a premature summer leaf fall, which may cover the riverbed (Sabater et al., 2001). During these episodes, the streambed shifts to a collection of pools, where the sedi- 
ments and organic detritus accumulate and the organisms remained confined (Lake 2003). Carbon limitation affects the microorganisms during these dry periods, and result in the enhancement of autotrophic production (Humphries and Baldwin, 2003).

Commonly, severe droughts in the Mediterranean climate are followed by intense rainfall periods that lead to major floods in the rivers. The transport of materials through the stream flow path after such periods might be affected by the nature of the organic matter accumulated during drought. During the progression from drought to water flowing conditions in autumn, nitrate and DOC mobilize to the stream water (Bernal et al., 2002; Butturini et al., 2003), and these increasing peaks can be very important for the biota, and particularly for the heterotrophic community.

The response of the microorganisms has been analysed in the Fuirosos stream (a third-order Mediterranean stream located at the MontnegreCorredor Natural Park, in NE Spain). This is an intermittent stream that usually dries out between June and the end of August. A peak of biodegradable DOC (BDOC) has been measured after the drought period and following the first rains at late-summer first-autumn. However, the fast disappearance of these labile and large molecules (most of them $>100 \mathrm{kDa}$ ), as well as their utilization and retention in the stream-riparian phreatic interfase indicate a fast utilization by the benthic microbial community. The seasonal study performed in this stream also show a relevant increase of the heterotrophic activities mainly related to the decomposition of organic matter such as extracellular enzyme activities and respiration, specially after a dry summer. Increases of $\beta$-glucosidase, $\beta$-xylosidase and cellobiohydrolase, indicate the utilization of plant-derived material such as cellulose and hemicellulose accumulated in the river bed (Fig. 4). During this period, the river ecosystem is highly heterotrophic (respiration values higher than $30 \mathrm{mg} \mathrm{O}_{2} \mathrm{~m}^{2} \mathrm{~h}^{-1}$, Acuña et al., 2004). Similar behaviour of the extracellular enzyme activities was observed in a larger river, the Ter, where activities increased in autumn, being positively correlated with an
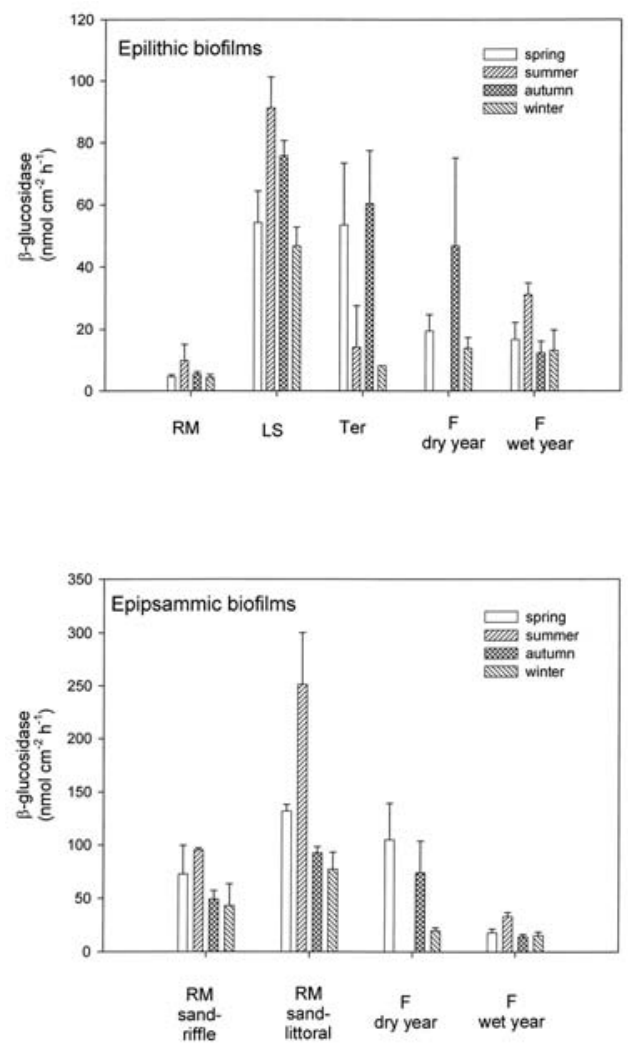

Figure 4. $\beta$-Glucosidase exoenzymatic activity in different Mediterranean streams. Data are shown on biofilms growing on rocky substratum (epilithic, top graph) and on sandy substratum (epipsammic, bottom graph). La actividad exoenzimática $\beta$-Glucosidasa en diferentes ríos Mediterráneos. Los valores se muestran en biofilms recogidos sobre piedras (epilithic, parte superior) y sobre arena (episammic, parte inferior).

increase in discharge and DOC content in the river water (Romaní and Sabater, 1999).

The pattern of DOC availability by the microbial heterotrophs is related to the seasonal discharge. In intermittent streams, the streambed completely dries out, and the existence of dry periods is associated to the high efficiency in the use of organic molecules when these are available (Romaní and Sabater, 1998). Calcium-saturated streams develop stromatolitic communities dominated by cyanobacteria. These stromatolitic communities are well adapted to extreme situations of floods and droughts (Sabater et al., 2000), an adaptation that is possible because of their thickness and the high porosity of the crust (Sabater, 2000). It has been experimentally established that the stromatolite recovers both its 
heterotrophic and autotrophic activities in a few hours, after being desiccated for long periods (Romaní and Sabater, 1997). High enzymatic activities have been measured after drought (Fig. 4). A rewetting experiment indicated that both the respiration and the photosynthetic activities were recovered after two hours of re-hydration, while the extracellular enzyme activities were recovered immediately. Recovery after desiccation is indicative of the high resilience of this community to environmental extremes, where the stromatolitic heterotrophs mainly rely on the organic carbon stored in the crust as the main organic carbon source. These strategies are the direct response of these communities to oligotrophy and desiccation, and justify the restricted occurrence in stream systems affected by organic pollution.

Other Mediterranean streams in less extreme environments show a similar pattern of response, even though less immediate. Short-time increases in extracellular enzyme activities are related to the accumulation of autochthonous and/or allochthonous organic matter on the streambed during spring and summer (Romaní and Sabater, 2000). In contrast, in wet years, when water is flowing even during summer, drastic fluctuations do not occur after the first rains, either in the DOC content or in the heterotrophic enzymatic activities and respiration (Fig. 4).

The second relevant factor in the heterotrophic metabolism in river biofilms is the availability of the benthic substratum type. This may be crucial to determine the biofilm structure (algae, bacteria, fungi biomass accrual, $\mathrm{C}, \mathrm{N}$ and $\mathrm{P}$ content, polysaccharide content) and function (photosynthetic activity, respiration, extracellular enzyme activities) (Romaní and Sabater, 2001, Artigas et al., 2004). In general, epipsammic biofilms show a much higher hydrolytic capacity (Fig. 4), underlying that sand is an important site for decomposi- tion, transformation and use of organic matter for the whole river ecosystem. The differences between epipsammic and epilithic biofilms in organic matter processing are related to the more complex structure of rocky biofilms, where algal biomass is higher and independent to seasonal fluctuations. However, sandy biofilms are less structured and dependent to fluctuations in the flowing water (Romaní and Sabater, 2001). Especially in epilithic biofilms (developing on rocks and cobbles) the close spatial relationship between bacteria and algae, as well as the fresh labile organic matter release by the autotrophs, determine the positive effect of algae on bacterial heterotrophic activity (Romaní and Sabater, 1999a, 2000a).

In situ and laboratory experiments have shown that a tight relationship exists between structure and function of benthic biofilms. Heterotrophic biofilms with a lower $\mathrm{C} / \mathrm{N}$ ratio are more efficient in the uptake of DOC from the river water, while biofilms growing under light conditions show a lower efficiency in water DOC uptake (Romaní et al., 2004). Differences are probably due to a major linkage between autotrophs and heterotrophs in the light-grown biofilms, as well as to the carbon cycling which characterizes the biological connections within the biofilm (Wetzel, 1993). The close contact between the algal and the heterotrophic community in attached lightgrown biofilms favours the use of algal material by microorganisms within the biofilm (Haack and McFeters, 1982; Nakano, 1996). Algal accumulation and activity enhances the heterotrophic use of organic matter by increasing the amount of substrate available for bacteria (Espeland et al., 2001; Romaní and Sabater, 1999). Organic carbon recycling within the biofilm (Wetzel, 1993) can reduce the dependence of the biofilm on organic carbon availability in the overlying river water (Freeman and Lock, 1995).

Table 1. Mean biomass ratios between functional feeding groups. Relaciones entre grupos tróficos a partir de los valores medios de biomasa.

\begin{tabular}{|c|c|c|c|c|c|c|c|c|c|c|c|c|}
\hline & \multicolumn{4}{|c|}{ Riera Major } & \multicolumn{4}{|c|}{ La Solana } & \multicolumn{4}{|c|}{ Fuirosos } \\
\hline & autumn & Winter & Spring & Summer & Autumn & Winter & Spring & Summer & Autumn & Winter & Spring & Summer \\
\hline Shredders/collectors & 24.4 & 0.94 & 0.80 & 0.52 & 1.23 & 0.16 & 0.06 & 0.50 & 2.28 & 0.56 & 0.02 & 0.01 \\
\hline Predators/total & 0.04 & 0.15 & 0.10 & 0.30 & 0.53 & 0.80 & 4.41 & 1.24 & 0.03 & 0.05 & 0.03 & 0.22 \\
\hline
\end{tabular}


Riera Major

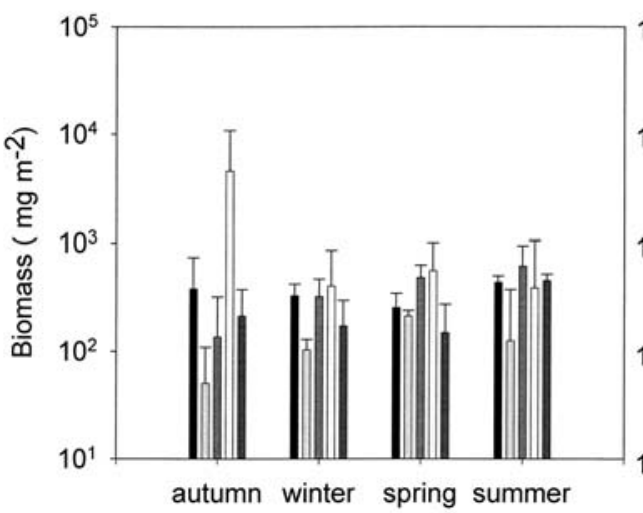

La Solana

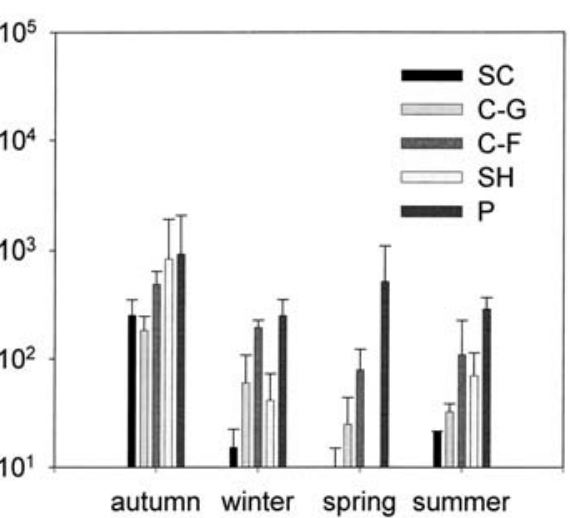

Figure 5. Mean biomass values of the different feeding groups of macroinvertebrates in two different Mediterranean streams characterising respectively a system with low flow fluctuation (Riera Major) and another with relevant flow fluctuations (La Solana). $\mathrm{SC}=$ Scrapers, $\mathrm{C}-\mathrm{G}=$ collector-gatherers, $\mathrm{C}-\mathrm{F}=$ collector-filterers, $\mathrm{SH}=$ shredders, $\mathrm{P}=$ predators. Bars show the standard deviation of the means (Modified from Muñoz, 2003). Valores medios de la biomasa de los diferentes grupos tróficos en dos rios Mediterráneos: de poca fluctuación en el caudal (Riera Major) y con importantes variaciones estacionales del caudal (La Solana). $S C=$ ramoneadores, $C-G=$ colectores, $C-F=$ filtradores, $S H=$ trituradores, $P=$ depredadores. Las barras muestran la desviación estándar (modificado de Muñoz, 2003).

\section{Heterotrophs using particulate organic carbon}

The indirect effects of discharge on the food availability to consumers may considerably influence the relative abundance of each functional feeding group (Angradi, 1996). In headwater streams elsewhere, shredders are the dominant functional feeding group in biomass terms, while collector-gatherers have the highest densities of all groups (Smock et al., 1989; Basaguren et al., 1996). Often, in Mediterranean streams collector-gatherers are accounting for the highest density and biomass (Muñoz, 2003; Acuña et al., 2005). This has been repeatedly observed in both siliceous and calcareous streams with a high degree of temporality, and this fact may be explained by the effect of floods on the organic matter availability. The frequent hydrologic disturbances that maintain non-equilibrium conditions, together with the relatively constant availability of fine detritus from upstream favour the predominance of collectors in most Mediterranean streams. Shredders are relevant only in autumn, the rest of the year being practically irrelevant (Fig. 5, Table 1). However, a gradient also exists within the same region. Mediterranean watercourses without relevant flow fluctuations and higher retention of coarse organic matter have the shredders being present all the year, while scrapers and collectors keep similar biomass values throughout the hydrological period (Muñoz, 2003).

Related with the above-described differences within Mediterranean streams, the temporal patterns of benthic organic matter accumulation (related itself with the hydrological conditions) determine the variation in the biomass distribution among functional feeding groups. Biomass ratios between shredders and collectors were higher throughout the year (Fig. 5, Table 1) in streams with more hydrological stability. The less variable Riera Major stream is characterised by a more stable, structurally complex and species-richer community. Although algal productivity was low, it was enough to maintain a substantial biomass of scrapers during the year. Detritivorous biomass was important together with the low seasonal variability in the stream (Muñoz, 2003). However, in the more variable Fuirosos stream, seasons preceded by stable hydrological periods and relatively high BOM in the river bed were characterised by longer chains and more complex food webs, while those less stable were the reverse. 


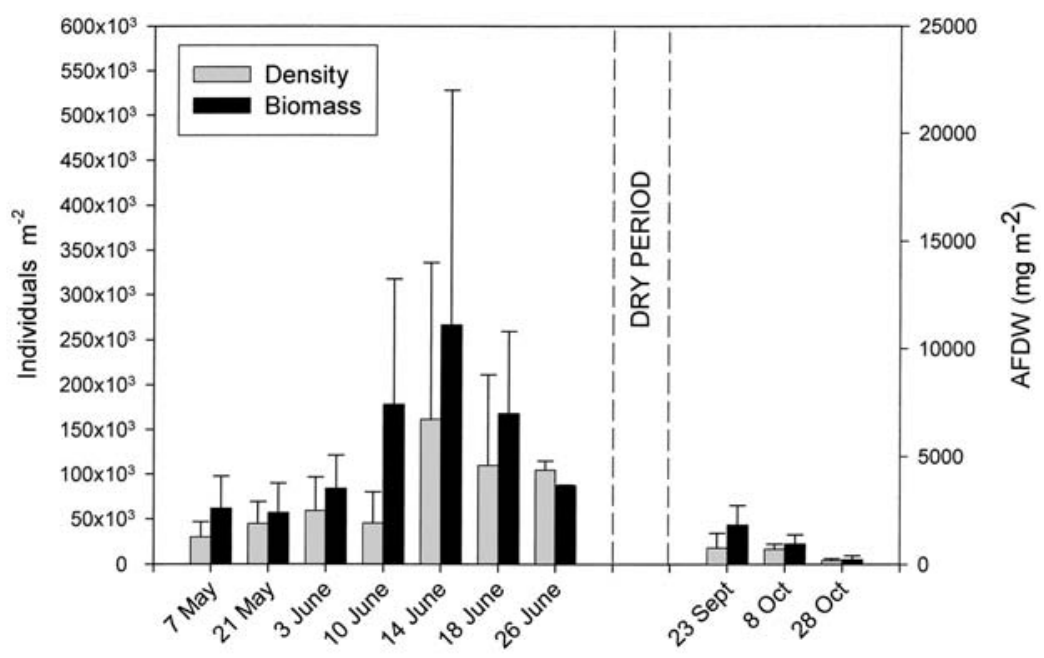

Figure 6. Mean density and biomass values of the macroinvertebrate community during a drought period (summer 2003) in Fuirosos stream. Bars show the standard deviation of the means. Valores medios de la densidad y la biomasa de los macroinvertebrados durante un periodo de sequía (verano 2003) en el río Fuirosos. Las barras muestran la desviación estándar.

Drought periods affect food availability. Flow reduction favours detritus concentration in some areas of the riverbed and its higher availability for the invertebrates, which increase in density and biomass (Fig. 6). On the other hand, pool isolation leads to an increase in the predation pressure (e.g. Stictotarsus sp., Notonecta maculata, Cordulegaster sp., Onychogomphus uncatus, Table 1). In many temporary streams, densities and biomass of predators rise sharply during the drying process (Stehr and Branson, 1938; Hynes, 1975; Abell, 1984; Stanley et al., 1994). Fragmentation in pools replace many rheophilous taxa by species more commonly found in lentic habitats, causing a general density decrease and the increase in the predation pressure (Boulton and Lake, 1992; Closs and Lake, 1996; Stanley et al., 1997).

Light availability in light-limited streams is not only able to determine seasonal changes in the primary producers (see above), but it also indirectly influences the consumer community since it enhances the biomass of high-quality food available. Removal of the riparian vegetation in Riera Major (Sabater et al., 1998) caused higher light availability, higher algal biomass and the subsequent biomass increase of some macroinvertebrates, mainly scrapers and collectors-filterers. Algae have lower $\mathrm{C}: \mathrm{N}$ ratios than other primary food resources in streams and are more efficiently digested (Allan, 1995; Hawkins and Sedell, 1981). Although a strict separation of top-down and bottom-up controls is unrealistic (Leibold et al., 1997), higher light availability in Mediterranean streams exerts a bottomup control on macroinvertebrate community.

Nutrients also can affect the outcome of the macroinvertebrate community. An experimental nutrient addition (during 44 days) in an oligotrophic Mediterranean stream caused the increase of the grazer Ancylus fluviatilis and the detritivorous Rheocricotopus spp. and Lumbriculidae (Sabater et al., 2005). Snails took advantage of the increased algal biomass, while nutrient addition changed detritus quality through increased biomass of nutrient-rich microfauna, and therefore increased the growth of detritivorous (Cross et al., 2005). These changes did occur in spite of the short period of nutrient enrichment, and indicated that the effects of nutrients could well extend to the upper components of the trophic food web in the streams.

\section{CONCLUSIONS}

The spatial heterogeneity of habitats (riparian cover, pools and riffles) and substrata (rocks, cob- 
bles, sediments) are essential elements for the biological communities in river systems. In Mediterranean rivers, the relationship between the habitat and the biological communities is modulated by the seasonal changes in water flow and light, as well as by the nutrient availability. This is evidenced by the structural-functional characteristics of the benthic communities and its role on the carbon production and cycling in Mediterranean rivers. Light availability determines the potential effect of nutrients in the primary producers. Discharge patterns determine leaf accumulation and DOC availability, respectively affecting the macroinvertebrate community and the microbial use of the allocthonous organic matter. In systems that suffer an extended drought period, heterotrophic activity is especially enhanced just after drought, while macroinvertebrate adapt to this extreme situation by reshaping their trophic structure. Mediterranean streams with well-preserved benthic habitat are efficient users of inorganic and organic materials. However, nutrient enhancement may produce a shift towards the predominance of autotrophs and a progressive change in the trophic structure of the river.

\section{ACKNOWLEDGEMENTS}

Ramon Margalef stated that "...(the river) is an example of the gradual accumulation of information, that guides the subsequent energy degradation and introduces a regular process of self-organisation". This paper is dedicated to his memory, and as a simple recognition of his stimulus in the study of the biological communities in rivers. Funds for the paper were provided by the CICYT REN2002-04442-C02 / GLO and CGL2005-06739-C02/BOS from the Spanish Science Ministry.

\section{REFERENCES}

ABELL, D. L. 1984. Benthic invertebrates of some California intermittent streams. In: Vernal pools and intermittent streams. S. Jain \& P. Moyle (eds): 46-60. Institute of Ecology, Davis, California.
ACUÑA, V., A. GIORGI, I. MUÑOZ, U. UEHLINGER \& S. SABATER. 2004. Flow extremes and benthic organic matter shape the metabolism of a headwater Mediterranean stream. Freshwat. Biol., 49: 960-971.

ACUÑA, V., I. MUÑOZ, A. GIORGI, M. OMELLA, F. SABATER \& S. SABATER. 2005. Drought and post drought recovery cycles in an intermittent Mediterranean stream: structural and functional aspects. J. North Am. Benthol. Soc., 24(4): 919-933.

ALLAN, J. D. 1995. Stream ecology. Structure and Function of Running Waters. Chapman and Hall. 388 pp.

ANGRADI, T. R. 1996. Inter-habitat variation in benthic community structure, function, and organic matter storage in three Appalachian headwater streams. J. North Am. Benthol. Soc., 15: 42-63.

ARMENGOL J., S. SABATER, A. VIDAL \& F. SABATER. 1991. Using the rescaled range analysis for the study of hydrological records: the River Ter as an example. In: Homage to Ramon Margalef, or why there is such a pleasure in studying nature. J. D. Ros, N. Prat (eds.): 21-33. Barcelona. Univ. Barcelona.

ARTIGAS J., A. M. ROMANI \& S. SABATER. 2004. Organic matter decomposition by fungi in a Mediterranean forested stream: contribution of streambed substrata. Annales de LimnologieInternational Journal of Limnology, 40: 269-77.

BASAGUREN, A., A. ELOSEGUI \& J. POZO. 1996. Changes in the trophic structure of benthic macroinvertebrate communities associated with food availability and stream flow variations. Internationale Revue Der Gesamten Hydrobiologie, 81: 79-91.

BERNAL, S., A. BUTTURINI \& F. SABATER. 2002. Variability of DOC and nitrate responses to storms in a small Mediterranean forested catchment. Hydrology And Earth System Sciences, 6: 1031-41.

BIGGS, B. J. F. 2000. Eutrophication of streams and rivers: dissolved nutrient-chlorophyll relationships for benthic algae. J. North Am. Benthol. Soc., 19(1): 17-31.

BOULTON, A. J. \& P. S. LAKE. 1992. The ecology of two intermittent streams in Victoria, Australia. Temporal changes in faunal composition. Freshwat. Biol., 27: 123-138.

BREITBURG D. L., J. W.BAXTER, C. A. HATFIELD, R. W. HOWARTH, C. G. JONES, G. M. LOVETT, C. WIGAND. 1998. Understanding 
effects of multiple stressors: Ideas and challenges. In: Successes, Limitations, and Frontiers in Ecosystem Science. PACE, M.L. \& GROFFMAN, P. M. (eds.). 416-31. New York.

BUTTURINI, A., S. BERNAL, E. NIN, C.HELLIN, L. RIVERO, SABATER, S. \& SABATER, F. 2003. Influences of the stream groundwater hydrology on nitrate concentration in unsaturated riparian area bounded by an intermittent Mediterranean stream. Water Resources Research, 39: $1-13$

CLOSS, G. P. \& P. S. LAKE, 1996. Drought differential mortality and the coexistence of a native and a introduced fish species in a south east Australian intermittent stream. Environmental Biology of Fishes, 47: 17-26.

CROSS, W. F., B. R. JOHNSON, J. B. WALLACE, A. D. ROSEMOND, 2005. Contrasting response of stream detritivores to long-term nutrient enrichment. Limnol. Oceanogr., 50 (6): 1730-1739.

CUMMINS, K. W., R. C. PETERSEN \& F. O. HOWARD. 1973. The utilization of leaf litter by stream detritivores. Ecology, 54: 336-345.

CUMMINS, K. W., M. A. WILZBACH, D. M. GATES, J. B. PERRY \& W. B. TALIAFERRO. 1989. Shredders and riparian vegetation: leaf litter that falls into streams influences communities of stream invertebrates. BioScience, 39: 24-30.

DRAKE, J. A. 1984. Species aggregation: the influences of detritus in a benthic invertebrate community. Hydrobiologia, 112: 109-115.

EGGLISHAW, H. J. 1964. The distributional relationship between the bottom fauna and plant detritus in streams. Journal of Animal Ecology, 38: 19-33.

ESPELAND E. M., S. N. FRANCOEUR \& R. G. WETZEL 2001. Influence of algal photosynthesis on biofilm bacterial production and associated glucosidase and xylosidase activities. Microbial Ecology, 42: 524-30.

FISHER, S. G. \& G. E. LIKENS. 1973. Energy flow in Bear Brook, New Hampshire: an integrative approach to stream Ecosystem Metabolism. Ecological Monographs, 43: 421-439.

FREEMAN, C. \& M. A. LOCK 1995. The biofilm polysaccharide matrix: A buffer against changing organic substrate supply? Limnol. Oceanogr., 40: 273-8.

GASITH, A. \& V. H. RESH 1999. Streams in Mediterranean climate regions: abiotic influences and biotic responses to predictable seasonal events. Annual review of Ecology and Systematic, 30: 51-81.
GUASCH, H. 1995. Primary production of epilithic biofilms in Mediterranean streams. Ph.D. Thesis. University of Barcelona. $211 \mathrm{pp}$.

GUASCH, H. \& S. SABATER, 1994. Primary production of epilithic communities in undisturbed Mediterranean streams. Verh. Internat. Verein. Limnol., 25:1761-4.

GUASCH, H. \& S. SABATER, 1995. Seasonal variation in photosynthesis-irradiance responses by biofilms in Mediterranean streams. J. Phycol., 31:725-35.

GUASCH, H., E. MARTÍ \& S. SABATER. 1995. Nutrient enrichment effects on biofilm metabolism in a Mediterranean stream. Freshwat. Biol., 33, 373-383.

GUASCH, H., J. ARMENGOL, E. MARTÍ \& S. SABATER. 1998. Diurnal Variation in dissolved oxygen and carbon dioxide in two low-order streams. Water Research, 32: 1067-1074.

HAACK, T. K. \& G. A. MCFETERS. 1982. Nutritional Relationships Among Microorganisms in an Epilithic Biofilm Community. Microbial Ecology, 8: 115-26.

HAWKINS, C. P. \& J. R. SEDELL. 1981. Longitudinal and seasonal changes in functional organization of macroinvertebrate communities in four Oregon streams. Ecology, 62:387-397.

HUMPHRIES P. \& D. S. BALDWIN. 2003. Drought and aquatic ecosystems: an introduction. Freshwat. Biol., 48: 1141-6.

HYNES, J. D. 1975. Annual cycles of macroinvertebrates in a river in southern Ghana. Freshwat. Biol., 5: 71-83.

LAKE, P. S. 2003. Ecological effects of perturbation by drought in flowing waters. Freshwat. Biol., 48: 1161-72.

LAMBERTI, G. A. \& A. D. STEINMAN. 1997. A comparison of primary production in stream ecosystems. J. North Am. Benthol. Soc., 16: 95-104.

LEIBOLD, M. A., J. M. CHASE, J. B. SHURIN \& A. L. DOWNING. 1997. Species turnover and the regulation of trophic structure. Annual Review of Ecology and Systematics, 28: 467-494.

MARGALEF, R. 1983. Limnología. Barcelona. Ed. Omega. 1010 pp.

MARTÍ, M \& F. SABATER. 1996. High variability in temporal and spatial nutrient retention in Mediterranean streams. Ecology, 77: 854-869.

MEYBECK, M. \& R. HELMER. 1989. The quality of rivers: from pristine stage to global pollution. Paleogeography, Paleoclimatology, Paleoecology. 75: 283-309. 
MEYER, E. 1991. Pattern of invertebrate community structure, abundance and standing crop in a Black Forest stream: Result of a 3-year study. Ver. Internat. Verein. Limnol., 24: 1840-1845.

MULHOLLAND, P. J., C. S. FELLOWS, J. L. TANK, GRIMM, N. B., WEBSTER, J. R., HAMILTON, S. K., MARTI, E., ASHKENAS, L., BOWDEN, W. B., DODDS, W. K., MCDOWELL, W. H., PAUL, M. J., PETERSON, B. J.2001. Interbiome comparison of factors controlling stream metabolism. Freshwat. Biol., 46: 1503-1517.

MUÑOZ, I. 2003. Macroinvertebrate community structure in an intermittent and a permanent Mediterranean streams (NE Spain). Limnetica, 22: 107-116.

NAKANO, S. 1996. Bacterial response to extracellular dissolved organic carbon released from healthy and senescent Fragilaria crotonensis (Bacillariophyceae) in experimental systems. Hydrobiologia, 339: 47-55

REAL, M., I. MUÑOZ, H. GUASCH, E. NAVARRO $\&$ S. SABATER. 2003. The effect of copper exposure on a simple aquatic food chain. Aquatic Toxicology, 63: 283-91

RESH, V. E., A. V. BROWN, A. P. COVICH, M. E. GURTZ, H. W. LI, G. W. MINSHALL, S. R. REICE, A. L. SHELDON, J. B. WALLACE \& R. C. WISSMAR. 1988. The role of disturbance in stream ecology. J. North Am. Benthol. Soc., 7: 433-55

ROBERTS, S., S. SABATER \& J. BEARDALL 2004. Benthic microalgal colonization in streams of differing riparian cover and light availability. $J$. Phycol., 40: 1004-12

ROMANI, A. M. \& S. SABATER 1997. Metabolism recovery of a stromatolitic biofilm after drought in a Mediterranean stream. Archiv für Hydrobiologie, 140: 261-71

ROMANI, A. M. \& S. SABATER 1998. A stromatolitic cyanobacterial crust in a Mediterranean stream optimizes organic matter use. Aquatic Microbial Ecology, 16: 131-41.

ROMANI, A. M., S. SABATER. 1999. Epilithic ectoenzyme activity in a nutrient-rich Mediterranean river. Aquat. Sci., 61: 122-32

ROMANI, A. M.\& S. SABATER 1999. Effect of primary producers on the heterotrophic metabolism of a stream biofilm. Freshwat. Biol., 41: 729-36.

ROMANI, A. M, \& S. SABATER 2000. Variability of heterotrophic activity in Mediterranean stream biofilms: A multivariate analysis of physical-chemical and biological factors. Aquat. Sci. 62: 205215.
ROMANI, A. M., S. SABATER. 2000a. Influence of algal biomass on extracellular enzyme activity in river biofilms. Microbial Ecology, 40: 16-24

ROMANI, A. M.\& S. SABATER 2001. Structure and activity of rock and sand biofilms in a Mediterranean stream. Ecology, 82: 3232-45

ROMANI,A. M., H. GUASCH, I. MUÑOZ, J. RUANA, E. VILALTA. 2004. Biofilm structure and function and possible implications for riverine DOC dynamics. Microbial Ecology, 47: 316-28

SABATER, S. 2000. Structure and architecture of a stromatolite from a Mediterranean stream. Aquatic Microbial Ecology, 21: 161-8

SABATER, F, H.GUASCH, E.MARTÍ, J. ARMENGOL \& S.SABATER 1995. The Ter: a Mediterranean river case-study in Spain. In: River ecosystems of the world, ed. CE Cushing, KW Cummins, GW Minshall, pp. 419-38. Amsterdam: Elsevier

SABATER, S., S.,V. GREGORY \& J.,R. SEDELL 1998. Community dynamics and metabolism of benthic algae colonizing wood and rock substrata in a forest stream. Journal of Phycology, 34: 561-567

SABATER, S., H. GUASCH, A. ROMANÍ \& I. MUÑOZ. 2000. Stromatolitic communities in Mediterranean streams: adaptations to a changing environment. Biodiversity and Conservation, 9: 379-392.

SABATER, S., S. BERNAL, A. BUTTURINI, E. NIN \& F. SABATER. 2001. Wood and leaf debris input in a Mediterranean stream: the influence of riparian vegetation. Arch. Hydrobiol., 153: 91-102

SABATER, S., E. VILALTA, A. GAUDES, H. GUASCH, I. MUÑOZ \& A. ROMANI. 2003. Ecological implications of mass growth of benthic cyanobacteria in rivers. Aquatic Microbial Ecology, 32: 175-84

SABATER, S., V. ACUÑA, A. GIORGI, E. GUERRA, I. MUÑOZ \& A. M. ROMANI. 2005. Effects of nutrient inputs in a forested Mediterranean stream under moderate light availability. Archiv für Hydrobiologie, 163: 479-96

SACHSE, A., R. HENRION, J. GELBRECHT \& C. E. W. STEINBERG. 2005. Classification of dissolved organic carbon (DOC) in river systems: Influence of catchment characteristics and autochthonous processes. Organic Geochemistry, 36: 923-35

SLAVIK, K., B. J. PETERSON, L. A. DEEGAN, W. B. BOWDEN, A. E. HERSHEY \& J. E. HOBBIE. 2004. Long-term responses of the Kuparuk river 
ecosystem to phosphorus fertilization. Ecology, 85: $939-54$

SMOCK, L. A., G. M. METZLER \& J. E. GLADDEN. 1989. Role of debris dams in the structure and functioning of low-gradient headwater streams. Ecology, 70: 764-775

STANLEY, E. H., S. G. FISHER \& N. B. GRIMM. 1997. Ecosystem expansion and contraction in streams. BioScience, 47: 427-435.

STEVENSON, R. J. 1997. Scale-dependent determinants and consequences of benthic algal heterogeneity. J. North Am. Benthol. Soc,. 16: 248-262.

STEHR, W. C. \& J. W. BRANSON. 1938. An ecological study of an intermittent stream. Ecology, 19: 294-310.
THORNDYCRAFT, V. R., G. BENITO, M. RICO, A. SOPEÑA, Y. SÁNCHEZ-MOYA, \& A. CASAS. 2005. Long-term flood discharge record derived from slackwater flood deposits of the Llobregat River, NE Spain. Journal of Hydrology 313: 16-31.

VELASCO, J., A. MILLAN, M. R. VIDAL-ABARCA, M. L. SUAREZ, C. GUERERO \& M. ORTEGA. 2003. Macrophytic, epipelic and epilithic primary production in a semiarid Mediterranean stream. Freshwat. Biol., 48: 1408-1420.

WETZEL, R. G. 1993. Microcommunities and microgradients: linking nutrient regeneration, microbial mutualism and high sustained aquatic primary production. Neth. J. Aquat. Ecol., 27: 3-9. 